\title{
A narrative synthesis of illustrative evidence on effects of capitation payment for primary care: lessons for Ghana and other low/middle-income countries
}

\author{
Francis-Xavier Andoh-Adjei ${ }^{1}$, Ernst Spaan $^{2}$, Felix A. Asante ${ }^{3}$ Sylvester A. Mensah $^{4}$ and Koos van \\ der Velden ${ }^{5}$
}

Ghana Med J 2016; 50(4): 207-219 DOI: http://dx.doi.org/10.4314/gmj.v50i4.3

\begin{abstract}
${ }^{1}$ National Health Insurance Authority - Research, Policy, Monitoring \& Evaluation, Accra, Greater Accra, Ghana ${ }^{2}$ Radboud University Medical Centre, Radboud Institute for Health Sciences - Department for Health Evidence, Nijmegen, Netherlands ${ }^{3}$ University of Ghana, Institute of Statistical, Social and Economic Research, Accra, Ghana ${ }^{4}$ University of Professional Studies, Centre for Universal Health Coverage, Accra, Ghana ${ }^{5}$ Radboud University Medical Centre, Radboud Institute for Health Sciences - Department for Primary Care, Nijmegen, Netherlands
\end{abstract}

Corresponding author: Francis-Xavier Andoh-Adjei $\quad$ E-mail: francis.adjei@nhia.gov.gh

Conflict of interest: None declared

\section{SUMMARY}

Objective: To analyse and synthesize available international experiences and information on the motivation for, and effects of using capitation as provider payment method in country health systems and lessons and implications for low/middle-income countries.

Methods: We did narrative review and synthesis of the literature on the effects of capitation payment on primary care.

Results: Eleven articles were reviewed. Capitation payment encourages efficiency: drives down cost, serves as critical source of income for providers, promotes adherence to guidelines and policies, encourages providers to work better and give health education to patients. It, however, induces reduction in the quantity and quality of care provided and encourages skimming on inputs, underserving of patients in bad state of health, "dumping" of high risk patients and negatively affect patient-provider relationship.

Conclusion: The illustrative evidence adduced from the review demonstrates that capitation payment in primary care can create positive incentives but could also elicit un-intended effects. However, due to differences in country context, policy makers in Ghana and other low/middle-income countries may only be guided by the illustrative evidence in their design of a context-specific capitation payment for primary care.

Funding: Netherlands Fellowship Programme (NFP), Fellowship number: NFP-PhD.12/352

Keywords: Capitation payment, primary care, cost-containment, national health insurance, Ghana

\section{INTRODUCTION}

There is growing demand for more health care within budgetary constraints, making it imperative for governments to implement cost-containment measures to ensure uninterrupted provisioning of health care services for their populations without compromising quality. ${ }^{1,2}$ Such cost-containment measures may be embedded in health sector reforms that apply various strategies such as making hospitals autonomous, implementing provider-purchaser split ${ }^{3,4}$ and reforming the provider payment system. ${ }^{2,5}$ The literature provides many forms of payment methods, including salary, budgetary transfers, fee-for-service, case-based/diagnosis-related-group (DRG), capitation payment, pay-for-performance and mixed methods. ${ }^{1,6,7}$ It must be acknowledged that each payment method elicits specific response from providers and, therefore, countries contemplating the adoption of any payment method may have to study the implementation experience of pioneering countries to understand the issues that these payment methods raise in order to inform their country-specific design. In Canada policy makers sought guidance from the literature in their choice of payment method. ${ }^{8}$ The National Health Insurance Authority (NHIA) in Ghana, as part of its provider payment reforms, is exploring capitation payment for primary care and this study seeks to scan available literature and synthesize illustrative evidence on effects of 
capitation payment for primary care in order to contribute to on-going discussion of the payment reforms in Ghana. Findings will also provide useful lessons for other health insurance agencies in low/middle-income countries. We seek to addresses three specific study questions: (i) what has been the motivation for implementing capitation payment in countries' health care systems? (ii) What effects has capitation payment had on primary care provision? (iii) What lessons can Ghana and other low/middle income countries learn from these international experiences? We begin by reflecting on the considerations underlying provider payment methods in an attempt to address study question one; and then narrow the focus on effects of capitation payment to adduce illustrative evidence to address study question two. Study question three will be addressed in the concluding part of the discussion where recommendations would be offered the NHIA and other health insurance agencies in low/middle-income countries that may be considering capitation payment for primary care.

\section{Considerations underlying provider payment}

The rationale for reforming provider payment systems has been the need for countries to contain the increasing cost of health care services without compromising quality. ${ }^{9,10,11}$ However, economic theory maintains that changes in provider payment systems attract responses from providers ${ }^{12}$ which could affect the quality and quantity of service provided. ${ }^{13}$ In the following paragraphs, we discuss key payment methods and the incentives they create in care delivery.

Fee-for-service payment is used to reimburse health care providers on "per item of service provided" basis and aligns provider income to quantity of service provided. ${ }^{7}$ While it helps to generate valuable health information to guide clinical decisions and draws providers' attention to patient satisfaction in order to retain them on their list, it may create incentives to increase service provision because the financial risk rests with the payer. ${ }^{14}$ It is described as reward for "volume and intensity rather than value"; and "inflationary and ineffective in containing cost". ${ }^{15}$ Barnum et al ${ }^{6}$ associate supplier-induced demand with fee-for-service but Rosen 14 argues that when providers advise patients in their capacity as agents in care delivery, their influence on patients' actions may only be described as "physicianinitiated" demand. Fee-for-service is widely used in countries such as Belgium, Germany and Japan. ${ }^{1}$ In many low/middle-income countries fee-for-service may be the dominant payment method for reimbursing provider but there are moves to adopt diagnosis-relatedgrouping (DRG) payment as part of measures to address the negative incentives of fee-for-service payment. ${ }^{16}$
In Ghana, the NHIA initially adopted fee-for-service payment but switched to DRG payment following the observed negative incentives that the fee-for-service created in the system.

DRG provides means for relating diagnosis and treatment to cost. Under DRG, providers are paid a predetermined amount for services rendered based on episode of illness with the initial motivation to provide framework for monitoring quality of care and utilization. ${ }^{17}$ It is deemed to have strong incentive to induce efficiency and cost-containment but requires quality control and monitoring systems to forestall possible perverse incentives. ${ }^{1}$ DRG was introduced by the United States Medicare programme to contain an observed increasing health care expenditure ${ }^{18}$ and a number of low/middle-income countries including Ghana are using various forms of DRG methods to reimburse their health care providers. ${ }^{16}$ In Ghana DRG rates are fixed in advance for a given diagnosis or diagnosis cluster but the reimbursement is made after the services have been rendered. Upon realization that the DRG creates incentives for providers to "game" the National Health Insurance Scheme (NHIS) the NHIA in Ghana is exploring capitation payment for primary care.

Under capitation payment, providers are paid agreed sum of money per insured member for a period of time to provide pre-determined services for enrolees. Two types of capitation systems may be identified: list capitation and geographic capitation. ${ }^{2,19}$ The list capitation payment ties the aggregate income of the provider to the number of patients enrolled to him/her while geographic capitation payment ties reimbursement to the population living within a particular geographical area. Capitation payment is expected to promote efficient use of resources by controlling prices and volumes of services provided. Payers of health care services have the benefit of knowing their budgets in advance under capitation payment; while providers pay attention to health literacy to keep their enrolees healthy in order to save cost. ${ }^{2}$ It is noted to eliminate supplier-induced demand associated with fee-for-service payment ${ }^{7,14}$ but, unless the capitated rate is risk-adjusted, at least by age and sex, providers may provide less care for perceived risk groups on their list. ${ }^{1,20}$ Many countries in the world, including the Scandinavian countries, United Kingdom (UK) and Thailand apply capitation payment but with variations. $^{21,22}$ The UK applies full risk-adjustment formula for calculating the capitated rate, Denmark adjust its capitated rate by age and sex while capitation rate in Thailand is determined by government and has no riskadjustment formula. ${ }^{21}$ Many countries in Central Europe and the Baltic states use capitation adjusted for age and sex to pay for primary care. ${ }^{23}$ Ghana introduced capita- 
tion payment for primary care service under its national health insurance scheme as a pilot project in 2012 and plans to scale it up across the country. Unlike many other countries, the capitated rate in Ghana is not riskadjusted. Besides, it is organised around institutional providers, be they public or private, who serve as the contracting unit of primary care whereas in many highincome countries, capitation is organized around General Practitioners (GPs).
We did a narrative review of the literature to present a synthesis of knowledge from published complementary studies on the effects of capitation payment. Narrative reviews are useful educational materials for faculties and for updating practitioners on clinical protocols and by discussing recent and best knowledge on a specific intervention from complementary (but not necessarily similar) studies. ${ }^{24,25}$

\section{METHODS}

Figure 1 Literature selection strategy

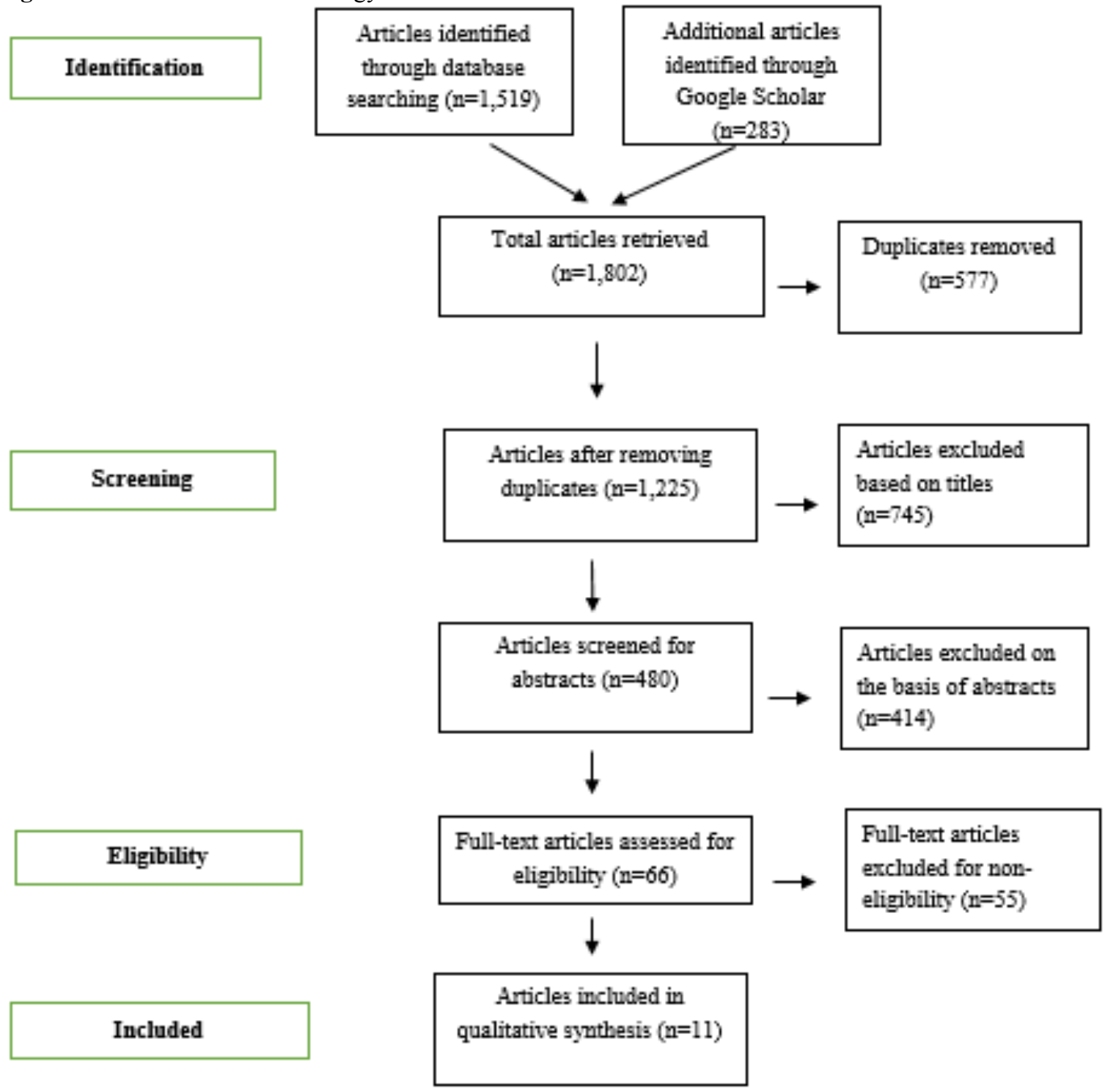

Source: Adapted from www.prisma-statement.org (2009)

We searched for articles in PubMed, Science Direct, Web of Science and Google Scholar. We initially lim- ited the scope to low/middle-income countries (LMICs) but given the few articles found addressing the issues of 
interest, we expanded the scope beyond LMICs. Publications that addressed capitation-specific effects on primary care were considered for the final analysis (Table 1). Others that compared capitation with other payment methods, book chapters and technical working papers that analysed the motivation for, and effects of provider payment methods were considered for initial review to enrich the background discussion. Articles that did not address capitation-specific effects and those which study design and setting were not clearly stated were excluded. Figure 1 depicts the literature selection strategy.

Ethical approval for the study (certified protocol number: UG-ECH 057/13-14) was obtained from the University of Ghana Institute of Statistical, Social and Economic Research (ISSER) Ethics Committee for $\mathrm{Hu}-$ mans.

\section{RESULTS}

We present the results in two sections: description of the search results and findings on effects of capitation on primary care.

\section{Description of search results}

We retrieved 1,802 articles during our initial search. Removal of duplicates reduced them to 1,225 . We excluded 1,159 articles which did not meet the selection criteria during screening of titles and abstracts. Upon screening of the remaining 66 full text articles, we settled on 11 for final review and reporting: two from Asia, three from Europe and six from the Americas. Study design and methods for the studies that were used in the analysis included: cross-sectional survey, retrospective (study) analysis, controlled experimental investigation, longitudinal study and pre-post design with control group.

\section{Effects of capitation payment method}

In this section, we present the positive and negative incentives that capitation creates in primary care delivery.

\section{Positive effects}

The key motivation for implementing capitation payment in country health systems has been the desire to contain cost of care provision. Consistent with this motivation, we found in our review that capitation payment could help contain cost ${ }^{27}$ and serve as critical source of income for providers. ${ }^{26}$ It is associated with slower growth of health care expenditures on services that were found to be profitable under fee-for-service. ${ }^{27}$ Ponce et al ${ }^{28}$ report of cost saving of $29 \%$ and $21 \%$ on pharmaceutical and laboratory services respectively, under capitation payment. With regard to quality of care, capita- tion payment was found to encourage better standardization of care and improvement in clinical outcomes alongside cost reduction. ${ }^{28}$ Findings from studies in the Netherlands ${ }^{29}$ and Portugal ${ }^{28}$ also suggest that there could be no decrease in the quality of care provided under capitation payment. Glazier et al ${ }^{30}$ on their part did not find any significant difference in the comprehensiveness and continuity of care between capitated and fee-for-service patients. Regarding provider attitude towards work, we found that Primary Care Physicians (PCPs) worked better within capitation payment regime and felt that their patients had reasonable access to appropriate care. ${ }^{31}$ Capitation was found to be associated with increased adherence to policies and general guidelines on the part of providers ${ }^{29}$ and incentivized them to give health education to their patients ${ }^{32}$ with the view to keeping their clients healthy thereby reducing cost of providing curative health care services.

\section{Negative effects}

The negative effects of capitation were mostly noted in the areas of quantity and quality of care as well as patient-provider relationship. With regard to quantity of care, a study found that PCPs provide services lower than optimal for capitated patients and underserve patients in bad and intermediate state of health while similar patients with fee-for-service providers receive services higher than optimal with those in good and intermediate state of health being over served. ${ }^{33}$ It was noted that physicians on capitation payment administered fewer medication to chronic patients under capitation and used less expensive health personnel such as generalists to manage specialist conditions; and nurse-aides rather than nurses to provide care for capitated insured clients. ${ }^{26}$ Capitation was found to be associated with the shifting of potentially primary care services to other areas of care and as Glazier et $\mathrm{al}^{30}$ reported, providers under capitation payment experienced more visits to emergency department with higher proportion being semi-urgent and non-urgent. They had relatively higher number of in-patients visits than those in enhanced feefor-service practice and enrolled fewer new patients. In terms of quality care, private hospitals were found to use less expensive inputs to provide care for insured patients, provided fewer medicines to chronic patients and discriminating against higher cost insured clients by developing strategies to "dump" them. ${ }^{26}$ With regard to provider attitude, we noted that primary care physicians had a negative perception about the capitation payment with concerns over provider income and strained relationship with patients. ${ }^{31}$ Studies that reported on patientprovider relationship indicated that patients accessing healthcare from capitated physicians showed lower level of trust in their physicians ${ }^{34}$ and that were $36 \%$ more likely to switch their primary care providers than those 
with fee-for-service-paid providers. ${ }^{35}$ This finding was, however, contradicted in another study ${ }^{36}$ that did not establish any negative effect of capitation payment on patients' trust for primary care providers that were paid by capitation method.

\section{DISCUSSION}

In this section, we discuss findings/results of the review beginning with the motivation for implementing provider payment reforms in country health systems. We then focus the second part of the discussion on the effects of capitation on primary care delivery and conclude with some recommendations for consideration by Ghana and other low/middle-income countries.

\section{Motivation for introducing payment reforms in country health systems:}

We noted from the background studies that reforms in health system financing, including provider payment reforms, in both high and low/middle-income countries are driven by the need to improve efficiency in the provision and use of health care services with the view to containing cost of health care services. ${ }^{37,9,11,38,39,20}$ A major area of focus in the provider payment reform is geared towards the application of capitation payment. Medicare in the United States of America (USA) introduced payment reforms as a result of increasing expenditure it was experiencing. Hungary introduced capitation payment in 2008 to improve efficiency in the allocation of health care resources. ${ }^{40}$ In the Swedish healthcare system, characterized by provider-purchaser split and devolvement of financial responsibility to the county level, provider payment at primary care level follows patient's choice of provider and a system of fixed payment for registered patients is implemented. ${ }^{41}$ Consistent with these and other countries, the main objective for introducing capitation payment in Ghana is to contain cost while ensuring quality of care. It must, however, be noted that country specific context such as the gross national income per capita, the health expenditure per capita and the proportion of the gross domestic product devoted to health care influence the incentives that payment method creates. Ghana being a lowermiddle-income country has relatively low income per capita (PPP Intl. \$3) compared to Thailand in Asia (PPP Intl. \$13), the Netherlands in Europe (PPP Intl. \$ 43) and the United States in the Americas (PPP intl. \$ 53). Ghana's total expenditure on health per capita expressed in international dollars as of 2013 was \$214 compared with Thailand $(\$ 658)$, the Netherlands $(5,601)$ and the United States $(\$ 9,146)$. The proportion of GDP devoted to health in Ghana was 5.4\% in 2013 whereas the Netherlands and the United States devoted $12.9 \%$ and $17.1 \%$, respectively to their health sectors. (Ref: http://www.who.int/countries. Accessed on
11/05/2016). Besides, many countries apply payment methods differently as may be observed in the Netherlands where general practitioners are paid through a mix of capitation (Euro 52 per patient) and fee-for-service for each additional contact (Euro 9 for consultation). ${ }^{42}$ These and other contextual differences do not provide same conditions and motivation for the adoption of a particular payment method and the incentives created across countries. In the case of Ghana, therefore, research is needed to ascertain whether capitation payment would achieve the cost-containment objective for which it was introduced.

\section{Effects of capitation payment on primary care}

One of the expected positive effects of capitation implementation in Ghana was slow growth in cost of health care services. Consistent with this expectation, evidence on cost of health care services under capitation payment shows some cost reduction in care delivery, especially in the area of pharmaceutical products and use of diagnostic equipment. ${ }^{27,28}$ However, NHIA pays for drugs on fee-for-service basis and therefore cannot benefit from the cost reduction experienced in countries that include drugs in the capitated basket of services. The issue of whether or not to include medicines in the basket of capitated services in Ghana was hotly debated among key stakeholders. Whereas the NHIA had plans to include medicines in the capitated package of services, health care providers were not in favour of it, a stance that some analysts may construe as "defence mechanism" on the part of the (Community) Pharmacist to protect their business considering that many health facilities, especially the public and mission facilities, have pharmacies or dispensaries attached to them and may not refer patients to them to fill their prescription. On the part of managers of health facilities with dispensaries it may also be seen as a strategy to reject the perceived financial risk that may be associated with medicines being part of the capitated package of services.

With regard to quality of care, since evidence has shown that capitation payment encourages better standardization of care, improvement in clinical outcomes alongside cost reduction ${ }^{28}$ and is associated with increased adherence to policies and general guidelines ${ }^{29}$ the Ministry of Health would have to invest time and efforts in the capitation implementation process to secure its utmost benefit for the population. The finding that capitation payment incentivized providers to give health education to their patients ${ }^{32}$ and that there could be no decrease in the quality of care provided under capitation payment ${ }^{29,28}$ and the fact that providers worked better under capitation payment regime ${ }^{31}$ brings hope for Ghana, if the capitation payment policy is well implemented. This brings into focus the issue of managed competi- 
tion that the Thai capitation payment introduced among public and private providers ${ }^{26}$ and which incentivised the public providers to work better in order to maximize their income and to survive that "healthy" competition. In the same way, under capitation payment regime, providers in Ghana have to compete among themselves to catch the attention and win the trust of insured-patients in order to enlist and retain them in their service to maximize their income. The NHIA envisaged that capitation payment would help its credentialed providers with their financial planning and improve their income. Consistent with this expectation, evidence from the review shows that capitation payment serves as critical source of income to providers and had the ability to provide between $20 \%$ and $30 \%$ profit margin for private hospitals in Thailand. ${ }^{26}$ However, the evidence further indicates that Thai private providers had initially responded negatively to the introduction of capitation on the basis of perceived low rate of the capitated amount. In some cases, the perceived extra cost is shifted to the consumer through un-authorized co-payment. This has implication for Ghana. Many of NHIA's credentialed providers are private providers who earn their income from services provided to (insured) clients. There are also the mission health care providers whose salaries of their professional staff are paid from government budget but bear their capital, service and administrative expenditures on their own. These expenditures are paid from the income they generate from the services they provide to (insured) clients. With respect to government operated health facilities, although their salaries and capital expenditures are borne by government, they are required to generate adequate income from the services they provide to (insured) clients either through direct out-of-pocket payment or insurance to pay for their recurrent expenditures. A switch from fee-for-service and DRG to capitation payment without the capitated rate being accepted to be realistic by payers and providers may be viewed by the providers as negatively affecting their income flow, a situation which could incentivize them to "game" the system to make up for perceived income loss. Providers in Ghana complain about low rate of the capitated amount although this concern is not supported by evidence since neither the NHIA nor the provider group has done actual costing of services to determine the adequacy or otherwise of the capitated rate. It would, therefore, be in the interest of Ghana for both the NHIA and provider groups to support the Ministry of Health to undertake costing studies in order to determine the real cost of service provision to inform the calculation of the capitated rate.

Notwithstanding the positive effects of capitation, our review identified some negative effects in relation to quantity and quality of care as well as patients-provider relationship. A study of effects of compensation meth- ods on physicians perceived incentives to alter services to patients concluded that "the way physicians are compensated affect their incentives to increase or decrease services to patients", with capitation being associated with incentive to reduce the quantity of service to patients. ${ }^{43}$ This is corroborated by evidence from our review which points to a decline in quantity of service provided. ${ }^{26,30,33}$ Countries have tried to address the tendency of care providers shifting potentially primary care cases to other levels of care by providing additional incentives to encourage low utilization at the secondary level, but evidence shows that such interventions fail to achieve the desired effect. ${ }^{44}$

On quality of care evidence shows that capitation provides incentive for care providers to skim on inputs by using less expensive health personnel to provide care beyond their competence in order to maximize their income to compensate for perceived income $\operatorname{loss}^{26}$ and referring potentially primary care cases to higher levels. ${ }^{45,46,47}$ This behaviour undermines the costcontainment objective of capitation because potential low cost that would have been borne at the primary care level is pushed to higher levels to attract higher cost thereby increasing the overall cost burden on the entire health system. It could also provide basis for stakeholders who are opposed to capitation payment in Ghana for its perceived negative effects on care delivery to continue their objection to the policy. It may, however, be argued that resorting to the use of less expensive health personnel without any discriminatory intent could be understood as task-shifting which is acknowledged to be "the vanguard for the renaissance of primary health care ${ }^{, 48}$ Studies on task shifting ${ }^{49,50}$ report its usefulness in addressing human resource shortages in resourceconstrained economies, of which Ghana is not an exception. In China, one way of preventing providers from engaging in excessive cost reduction in response to payment reform and to assure quality of service was for the Social Insurance Bureau (the NHIA in the case of Ghana) to require that the number of patients treated by providers be at least $90 \%$ of the previous year's while their total spending should not be below $90 \%$ of budget. ${ }^{27}$ Such an intervention in Ghana will, however, require a robust monitoring and evaluation system to track performance in order not to create incentives for providers to duplicate utilization to benefit from un-earned claims. At the onset of capitation implementation in Ghana, the NHIA had to accept providers demand to take off maternal care services from the capitated basket of service since capitation was perceived to have potential to compromise the quality of maternal care. Contrary to this opinion however, evidence from Portugal showed that there was no decrease in the quality of care provided after capitation payment was introduced.$^{28}$ Besides, pa- 
tients accessing services from capitated primary care providers were found to be more likely to receive health education if their primary care providers were paid primarily by capitation method. ${ }^{32}$ These findings provide inspiration for Ghana to re-consider including maternal health care package in the capitated basket of services in the future.

On patient-provider relationship, though some evidence showed that patients were not comfortable with their physicians being reimbursed on capitation basis and expressed lower level of trust in their physicians ${ }^{34}$, a situation that systematically affected the doctor-patient relationship and patients who were expected to be loyal to their PCPs were found to be more likely to switch their PCPs if the latter was paid by capitation ${ }^{35}$ although some other evidence contradicted it. ${ }^{36}$ Besides, it must be noted that although patients' satisfaction surveys are acceptable mechanism for measuring quality from patients' perspectives and are good to explore views of patients on care they receive; and help providers to reflect on their services and adjust to meet clients' needs and expectations, patients' perception of quality may not necessarily reflect clinical quality. Some of the negative perception about the perceived quality of care received from providers may be caused by the asymmetry of knowledge between care providers and their clients. In the case of China, the negative perception expressed by respondents in the studies reviewed may have been influenced by the negative media reportage on the provider payment reform. ${ }^{51}$ In LMICs like Ghana where demand for providers is higher than supply, it could be difficult for patients to switch providers in protest against perceived poor quality of care received. It would, therefore, be commendable for policy makers and health insurance agencies in low and middleincome countries to collaborate with the media to promote such reforms while encouraging them to expose negative practices that could derail the reform agenda. The media should, however, not be a substitute for monitoring and evaluation, which is required to track performance and identify un-intended consequences for early redress.

\section{Lessons learned}

Apart from the evidence alluded to above, the review has brought to the fore issues that Ghana and other low and middle-income countries may consider as part of the adaptable lessons from pioneering countries implementing capitation payment system.

Firstly, it must be acknowledged that there are lots of constraints when it comes to the development of an efficient and effective provider payment mechanism, the most important constraint being availability of data on actual cost of services provided, volume of services produced and characteristics of the consumers of services. This is extremely so in low and middle-income countries, including Ghana where costing of health care services has been constrained by lack of credible data for better analysis. This calls for commitment and support of the Ministries of Health towards targeted studies on costing of health care services in order to provide realistic and evidence-based information for the development of system-wide provider payment systems. Such an intervention could help address the issue of whether or not the capitated rate is adequate.

Secondly, evidence from the study of patients' attitude towards their physicians financial incentives ${ }^{34}$ shows that more respondents with higher level of income and exposure to higher education expressed higher discomfort with their providers being paid by capitation and that their discomfort may have been influenced by their exposure to negative media reportage on reimbursement system for providers and the effect that such system has on their service provision. In Thailand, evidence shows that the media drew policy makers and the general public's attention to the negative practices that hospitals used to maximize their income from the capitated amount on the social security workers. ${ }^{26}$ The vibrant media landscape in Ghana provides opportunity for the NHIA to collaborate with the media to promote the positive attributes of capitation payment while at the same time encouraging the media to expose negative practices that may have the potential to derail the implementation process.

Thirdly, the NHIA may learn from the managed competition that came along with the introduction of capitation in Thailand. Evidence shows that the Social Security Scheme's capitation payment system introduced in Thailand brought awareness to the public hospitals that they were in competition with the private sector and this encouraged them to improve the quality of service they provided to keep them in the competition. ${ }^{26}$ They were incentivized to attract more clients to maximize their income since the quantum of their income did not depend any longer on the volume of services provided but rather the number of enrolees that stayed on their list. Such a healthy competition is needed in Ghana to enhance quality of service especially in the public sector and capitation offers an opportunity in that direction.

Fourthly, apart from the cost-containment and quality of care issues, capitation payment has the potential to incentivise managers of health facilities to keep to the optimal staffing levels in order to save cost and thereby help address the equity issues in the distribution of hu- 
man resource for health ${ }^{52}$ by re-distributing "excess" staff to underserved areas.

Finally, the NHIA may want to note that a switch to capitation payment requires intense involvement of all stakeholders, both in the preparation of the capitation package and in the organization and implementation of the reform. Besides, the NHIA would have to come to terms with the persistent tension that is expected between the technical accuracy of the formulae for calculating capitated rates and the desire for simplicity. While the former promotes efficiency and equity the latter promotes political accountability. Evidence from Hungary ${ }^{40}$ shows that such tension slowed down the formula development process and therefore the NHIA should not expect results from the policy reforms overnight but rather look up to a medium to long term period of 5 to 10 years for a successful completion of the process of defining a funding formula that meets the desired resource allocation goals and which successfully comprises risk adjustment, risk sharing and other complementary policies.

\section{CONCLUSION}

From the preceding discussion, one cannot but agree with Rosen that there is no perfect payment method in health care delivery. Each payment method has its strengths and weaknesses and different payment methods and incentives produce different effects in different contexts. Policy makers in Ghana and other low/middleincome countries would have to consider adapting the positive experiences to their country specific context while being cautioned by the negative effects and coveting them into opportunities for improvement. They may also want to appreciate the need for a mix of payment methods to leverage the positive incentives of each of them and mitigate their negative effects since there is no provider payment method that is a panacea to the rising health care cost.

\section{Limitations:}

The review was limited to publications in English. The number of articles included in the final analysis is limited to eleven articles out of which nine are set in high income countries with different health system and context from those of LMICs. Besides, the context in Ghana and other LMICs is not favorably comparable to that of the countries from which the articles were retrieved for the study. However, since the aim was to look for illustrative evidence for adaption to country specific situation, insights from the review bring relevant lessons to Ghana's NHIA and health insurance agencies in other low and middle-income countries that are considering capitation as payment method for primary out-patient care.

\section{REFERENCES}

1. World Health Organization. Provider payments and cost-containment: lessons from OECD countries. Technical brief for policy-makers (2). Park M, Braun T, Carrin G, Evans D. eds. World Health Organization. 2007; 1-7. [Internet] Available from: http://www.who.int. Accessed 28 May 2015.

2. Jegers M, Kesteloot K, De Graeve D, Gilles W. A typology for provider payment systems in health care. Health Policy (New York) 2002, 60(3):25573.

3. Duckett SJ. Hospital payment arrangements to encourage efficiency: the case of Victoria, Australia. Health Policy (New York) 1995, 34(2):113-34.

4. The International Bank for Reconstruction/World. Spending wisely. Buying health services for the poor. Preker AS, Langenbrunner JC. eds. Washington DC: The World Bank; 2005.

5. Petersen LA, Woodard LD, Urech T, Daw C, Sookanan S. Does Pay-for-Performance Improve the Quality of Health Care ? Ann Intern Med. 2006; 145(4):265-72.

6. Barnum H.; Kutzin J.; Saxeniam. Incentives and Provider Payment Methods. Int J Heal Policy Manag. 1995; 10:23-45.

7. Rudmik L, Wranik D, Rudisill-Michaelsen C. Physician payment methods: a focus on quality and cost control. J Otolaryngol - Head Neck Surg. 2014; 43(1):34.

8. Emery JCH, Auld C, Lu M. Paying for physician services in Canada: the institutional, historical and policy contexts [Internet]. 1999. Report No.: 99-6. Available from: http://portal.publicpolicy.utoronto.ca/... Physician Behaviour $\% 2 \ldots$

9. Abe T, Toyabe SI, Cao P, Kurashima S, Akazawa $\mathrm{K}$. Development of a simulation program for estimating hospital incomes under the prospective payment system. Comput Methods Programs Biomed. 2005, 80(3):271-6.

10. Agyei-Baffour P, Oppong R, Boateng D. Knowledge, perceptions and expectations of capitation payment system in a health insurance setting: a repeated survey of clients and health providers in Kumasi, Ghana. BMC Public Health. 2013; 13(13):1220.

11. Maceira D. Provider payment mechanisms in health care: Incentives, outcomes, and organizational impact in developing countries [Internet]. Major Applied Research. Bethesda, MD: Partnership for Health Reform Project; 1998. [Internet]. Available from: http://scholar.google.com/scholar. Accessed 26 May 2015. 
12. De Jaegher K, Jegers M. A model of physician behaviour with demand inducement. $J$ Health Econ. 2000, 19(2):231-58.

13. He D, Mellor JM. Hospital volume response to medicare's outpatient prospective payment system: Evidence from Florida. J Health Econ. 2012, 31(2):730-43.

14. Rosen B. Professional reimbursement and professional behavior: emerging issues and research challenges. Soc Sci Med. 1989; 29(3):455-62.

15. Econex. Provider payment systems [Internet]. South Africa; 2010. Report No.: 6. Available from: www.econex.co.za

16. Mathauer I, Wittenbecher F. Hospital payment systems based on diagnosis-related groups: experiences in low- and middle-income countries. Bull World Health Organ. 2013; 91(10):746-56A.

17. Averill RF, Goldfield N, Hughes JS, Bonazelli J, McCullough EC, Steinbeck B et al. All patient refined diagnosis related groups (APR-DRGs): methodology overview. 2003; 1-81. Available from: http://www.hcup-us.ahrq.gov/.../APR-

DRGsV20MethodologyOverview. Accessed 25 May 2015.

18. Grabowski DC, Afendulis CC, McGuire TG. Medicare prospective payment and the volume and intensity of skilled nursing facility services. $J$ Health Econ. 2011; 30(4):675-84.

19. Busse R, Stahl J. Integrated care experiences and outcomes in Germany, the Netherlands and England. Health Aff. 2014; 33(9):1549-58.

20. Randall PE, McGuire TG. Provider behaviour under prospective reimbursement: cost sharing and supply. J Health Econ. 1986; 5:129-51.

21. Scott A, Sivey P, Ait OD, AO, Willenberg L, Naccarella L, Furler J, et al. The effect of financial incentives on the quality of health care provided by primary care physicians (Review). Cochrane Database Syst Rev. 2011; 9(9):CD008451.

22. Waters HR, Hussey P. Pricing health services for purchasers-a review of methods and experiences. Health Policy (New York). 2004 70(2):175-84.

23. Szende A, Mogyorosy Z. Health care provider payment mechanisms in the new EU members of Central Europe and the Baltic states. Current reforms, incentives, and challenges. Eur J Heal Econ. 2004; 5(3):259-62.

24. Green BN, Johnson CD, Adams A. Writing narrative literature reviews for peer-reviewed journals: secrets of the trade. J Chiropr Med. 2006, 5(3):101-17.

25. Dijkers Marcel PJM. The value of "traditional" reviews in the era of systematic reviewing. Am J Phys Med Rehabil. 2009; 88(5):423-30.
26. Mills A, Bennett S, Siriwanarangsun P, Tangcharoensathien $\mathrm{V}$. The response of providers to capitation payment: a case-study from Thailand. Health Policy (New York). 2000, 51(3):163-80.

27. Yip W, Eggleston K. Addressing government and market failures with payment incentives: Hospital reimbursement reform in Hainan, China. Soc Sci Med. 2004, 58(2):267-77.

28. Ponce P, Marcelli D, Guerreiro A, Grassmann A, Gonçalves C, Scatizzi L. Converting to a capitation system for dialysis payment-the portuguese experience. Blood Purif. 2013; 34(3-4):313-24.

29. van Dijk CE, Verheij RA, Spreeuwenberg P, van den Berg MJ, Groenewegen PP, Braspenning J, de Bakker HD. Impact of remuneration on guideline adherence: empirical evidence in general practice. Scand J Prim Health Care. 2013, 31(1):56-63.

30. Glazier RH, Klein-Geltink J, Kopp A, Sibley LM. Capitation and enhanced fee-for-service models for primary care reform: a population-based evaluation. Can Med Assoc J. 2009; 180(11):E72-81.

31. Cykert S, Hansen C, Layson R, Joines J. Primary care physicians and capitated reimbursement: Experience, attitudes, and predictors. J Gen Intern Med. 1997; 12(3):192-4.

32. Pearson WS, King DE, Richards C. Capitated payments to primary care providers and the delivery of patient education. J Am Board Fam Med. 2013; 26(4):350-5.

33. Hennig-Schmidt H, Selten R, Wiesen D. How payment systems affect physicians' provision behaviour-an experimental investigation. $J$ Health Econ. 2011, 30(4):637-46.

34. Pereira AG, Pearson SD. Patient attitudes toward physician financial incentives. Arch Intern Med. 2001; 161(10):1313-7.

35. Sorbero MES, Dick AW, Zwanziger J, Mukamel D, Weyl N. The effect of capitation on switching primary care physicians. Health Serv Res. 2003; 38(1 Pt 1):191-209.

36. Hall MA, Dugan E, Balkrishnan R, Bradley D. How disclosing HMO physician incentives affects trust. Health Aff. 2002; 21(2):197-206.

37. Tang S, Tao J, Bekedam HB. Controlling cost escalation of healthcare: making universal health coverage sustainable in China. BMC Public Health. 2012; 12(58):1-13.

38. Bautista MCG, Babin SM. A handbook for the capitation payment mechanism for the outpatient benefit package of PhilHealth [Internet]. 2001. Available from: htpp://www.scribd.com/doc/72531636/Doc01CapitationHnBk

39. Randall PE, McGuire TG. Hospital response to prospective payment: Moral hazard, selection, and 
practice-style effects. $J$ Health Econ. 1996, 15(3):257-77.

40. Nagy B, Brandtmuller A. Implementing riskadjusted capitation payments with health care reforms in Hungary. Journal Econ Lit. 2008; 147-60.

41. World Health Organization. Sweden: health system review. Anell A, Glenngard AH, Merkur SM. eds. The European Observatory on Health Systems and Policies. 2012. [Internet] Available from: http://www.euro.who.int/en/who-weare/partners/observatory. Accessed 26 May 2015.

42. Paris V, Devaux M, Wei L. Health systems institutional characteristics: a survey of 29 OECD countries. 2010. Report No.: 50. [Internet] Available from: http://dx.doi.org/10.1787/5kmfxfq9qbnr-en. Accessed 26 May 2015.

43. Reschovsky JD, Hadley J, Landon BE. Effects of compensation methods and physician group structure on physicians' perceived incentives to alter services to patients. Health Serv Res. 2006; 41(4):1200-1220.

44. Hutchison B, Birch S, Hurley J, Lomas J, StratfordDevai F. Do physician-payment mechanisms affect hospital utilization? a study of health service organizations in Ontario. CMAJ. 1996; 154(5):653-61.

45. Stearns SC, Wolfe BL, Kindig DA. Physician responses to fee-for-service and capitation payment. Inquiry. 1992; 29(4):416-25.
46. Allard M, Jelovac I, Léger PT. Treatment and referral decisions under different physician payment mechanisms. J Health Econ. 2011, 30(5):880-93.

47. Mariñoso BG, Jelovac I. GPs' payment contracts and their referral practice. $J$ Health Econ. 2003; 22(4):617-35.

48. World Health Organization. Treat, train, retain: Task Shifting Global recommendations and guidelines. Organization. 2008; 96.

49. Fulton BD, Scheffler RM, Sparkes SP, Auh EY, Vujicic M, Soucat A. Health workforce skill mix and task shifting in low income countries: a review of recent evidence. Hum Resour Health. 2011, 9(1): 1 .

50. Callaghan M, Ford N, Schneider H. A systematic review of task- shifting for HIV treatment and care in Africa. Hum Resour Health. 2010; 8:8.

51. Yip W, Eggleston K. Provider payment reform in China: The case of hospital reimbursement in Hainan Province. Health Econ. 2001; 10(4):325-39.

52. Chaix-Couturier, C; Durand-Zaleski, I.; Jolly, D.; Durieux P. Effects of financial incentives on medical practice: results from a systematic review of the literature and methodological issues. Int J Qual Heal Care. 2000; 12(1):33-42. 


\section{Original Article}

\begin{tabular}{|c|c|c|c|c|c|c|c|}
\hline No. & $\begin{array}{l}\text { Study refer- } \\
\text { ence }\end{array}$ & $\begin{array}{l}\text { Country \& } \\
\text { characteristics }\end{array}$ & Study objective & Study design/method & Sample size & Major findings/conclusions & $\begin{array}{l}\text { Effect Positive (+) Nega- } \\
\text { tive(-) }\end{array}$ \\
\hline \multirow[t]{6}{*}{1.} & \multirow[t]{6}{*}{$\begin{array}{l}\text { Mills, A et } \\
\text { al, } 2000\end{array}$} & \multirow[t]{6}{*}{ Thailand } & \multirow{6}{*}{$\begin{array}{l}\text { To understand the internal } \\
\text { responses of providers to } \\
\text { the incentives inherent in } \\
\text { the capitation payment } \\
\text { mechanism. }\end{array}$} & \multirow{6}{*}{$\begin{array}{l}\text { Cross sectional survey } \\
\text { using extensive semi- } \\
\text { structured interviews } \\
\text { with managers and staff } \\
\text { of the study hospitals. }\end{array}$} & \multirow[t]{6}{*}{$\begin{array}{l}2 \text { main provider net- } \\
\text { works and } 9 \text { hospitals } \\
\text { in Bangkok }\end{array}$} & $\begin{array}{l}\text { Private hospitals use less expensive } \\
\text { inputs to provide care for insured cli- } \\
\text { ents under capitation payment. }\end{array}$ & Quality of care (-) \\
\hline & & & & & & $\begin{array}{l}\text { Private hospitals provide fewer medi- } \\
\text { cines to chronic patients as a cost- } \\
\text { containment measure. }\end{array}$ & $\begin{array}{l}\text { Quality/quantity of care } \\
\text { provided (-) }\end{array}$ \\
\hline & & & & & & $\begin{array}{l}\text { Some private hospitals developed strat- } \\
\text { egies to "dump" higher cost insured } \\
\text { clients and deter them from re- } \\
\text { registering with them. }\end{array}$ & $\begin{array}{l}\text { Quality of } \\
\text { care/discrimination (-) }\end{array}$ \\
\hline & & & & & & $\begin{array}{l}\text { Capitation provides strong incentives } \\
\text { for contracting between different pro- } \\
\text { viders }\end{array}$ & Provider attitude $(+)$ \\
\hline & & & & & & $\begin{array}{l}\text { Capitation encouraged the development } \\
\text { of provider networks due to accessibil- } \\
\text { ity concerns and relative over-capacity } \\
\text { among private hospitals in Bangkok } \\
\text { city. }\end{array}$ & Provider attitude $(+)$ \\
\hline & & & & & & $\begin{array}{l}\text { Capitation served as critical source of } \\
\text { income to providers and could generate } \\
\text { between } 20 \% \text { to } 30 \% \text { profit margins for } \\
\text { private hospitals in Thailand. }\end{array}$ & Provider income $(+)$ \\
\hline 2. & $\begin{array}{l}\text { Yip et al, } \\
2004\end{array}$ & China & $\begin{array}{l}\text { To identify effects of sup- } \\
\text { ply-side payment reform } \\
\text { on different categories of } \\
\text { expenditures }\end{array}$ & $\begin{array}{l}\text { Pre-post study designs } \\
\text { with control group- a } \\
\text { natural experiment. }\end{array}$ & $\begin{array}{l}6 \text { hospitals that are } \\
\text { cost drivers in Hainan- } \\
\text { China. }\end{array}$ & $\begin{array}{l}\text { Capitation payment is associated with a } \\
\text { slower rate of growth of expenditure on } \\
\text { services that are profitable under fee- } \\
\text { for-service. }\end{array}$ & Cost-containment $(+)$ \\
\hline \multirow[t]{3}{*}{3.} & \multirow[t]{3}{*}{$\begin{array}{l}\text { Ponce P et } \\
\text { al, 2013 }\end{array}$} & \multirow[t]{3}{*}{ Portugal } & \multirow{3}{*}{$\begin{array}{l}\text { To review the components } \\
\text { of the Portuguese Capita- } \\
\text { tion package, including } \\
\text { efficiency changes after the } \\
\text { introduction of capitation. }\end{array}$} & \multirow{3}{*}{$\begin{array}{l}\text { Retrospective (trend) } \\
\text { analyses of Portuguese } \\
\text { Nephro Care clinics } \\
\text { (from January 2008 to } \\
\text { December 2010) }\end{array}$} & \multirow[t]{3}{*}{$\begin{array}{l}34 \text { Portuguese Nephro } \\
\text { care Clinics with } 4,200 \\
\text { patients }\end{array}$} & $\begin{array}{l}\text { There was a clear improvement in } \\
\text { clinical outcome alongside cost reduc- } \\
\text { tion. }\end{array}$ & $\begin{array}{l}\text { Cost-containment/quality } \\
\text { of care }(+)\end{array}$ \\
\hline & & & & & & $\begin{array}{l}\text { There was } 29 \% \text { and } 21 \% \text { cost savings } \\
\text { on pharmaceutical and laboratory ser- } \\
\text { vices, respectively. }\end{array}$ & Cost-containment (+) \\
\hline & & & & & & $\begin{array}{l}\text { There was better standardization of care } \\
\text { under capitation payment. }\end{array}$ & Quality of care $(+)$ \\
\hline \multirow[t]{2}{*}{4.} & \multirow[t]{2}{*}{$\begin{array}{l}\text { Van Dijk C. } \\
\text { et al, } 2013\end{array}$} & \multirow[t]{2}{*}{$\begin{array}{l}\text { The Nether- } \\
\text { lands }\end{array}$} & \multirow{2}{*}{$\begin{array}{l}\text { To investigate whether } \\
\text { changes in GP remunera- } \\
\text { tion system through differ- } \\
\text { ent financial incentives } \\
\text { affected quality of care in } \\
\text { terms of guidelines adher- } \\
\text { ence }\end{array}$} & \multirow{2}{*}{$\begin{array}{l}\text { Longitudinal study } \\
\text { analysing differences in } \\
\text { trends for guidelines } \\
\text { adherence from } 2002 \text { to } \\
2009 \text { between publicly } \\
\text { and privately insured } \\
\text { patients. }\end{array}$} & \multirow{2}{*}{$\begin{array}{l}21,421 \text { to } 39,828 \\
\text { patients record from } \\
32 \text { to } 52 \text { general prac- } \\
\text { tices. }\end{array}$} & $\begin{array}{l}\text { General guidelines adherence increased } \\
\text { by } 7 \% \text { for publicly insured patients and } \\
10 \% \text { for privately insured patients. }\end{array}$ & Provider attitude $(+)$ \\
\hline & & & & & & $\begin{array}{l}\text { Changes in provider payment did not } \\
\text { have significant effect on guidelines } \\
\text { adherence between publicly insured and } \\
\text { privately insured patients. }\end{array}$ & Provider attitude $(+)$ \\
\hline
\end{tabular}




\section{Original Article}

\begin{tabular}{|c|c|c|c|c|c|c|c|}
\hline 5. & $\begin{array}{l}\text { Pearson et al. } \\
(2013)\end{array}$ & USA & $\begin{array}{l}\text { To determine whether } \\
\text { capitation payment to } \\
\text { primary care providers is } \\
\text { associated with patient } \\
\text { education being included } \\
\text { more frequently during } \\
\text { office visits compared with } \\
\text { other payments. }\end{array}$ & $\begin{array}{l}\text { Cross-sectional analysis } \\
\text { of patients' visit to } \\
\text { primary care providers } \\
\text { using the } 2009 \text { National } \\
\text { Ambulatory Care Sur- } \\
\text { vey data. }\end{array}$ & $\begin{array}{l}9,863 \text { patient visits in } \\
\text { which capitation status } \\
\text { was available and } \\
\text { provider was the pa- } \\
\text { tients' primary care } \\
\text { provider. }\end{array}$ & $\begin{array}{l}\text { Patients were more likely to receive } \\
\text { health education from providers paid } \\
\text { primarily by capitation method. }\end{array}$ & Provider attitude $(+)$ \\
\hline \multirow[t]{3}{*}{6.} & \multirow[t]{3}{*}{$\begin{array}{l}\text { Glazier R. H } \\
\text { et al, } 2009\end{array}$} & \multirow[t]{3}{*}{ Canada } & \multirow{3}{*}{$\begin{array}{l}\text { To evaluate practice char- } \\
\text { acteristics and patterns } \\
\text { under capitation and en- } \\
\text { hanced fee-for-service. }\end{array}$} & \multirow[t]{3}{*}{$\begin{array}{l}\text { Retrospective cohort } \\
\text { study using administra- } \\
\text { tive data }\end{array}$} & \multirow[t]{3}{*}{$\mathrm{n} / \mathrm{a}$} & $\begin{array}{l}\text { Patients in capitated practice had less } \\
\text { after work hours of care and more visits } \\
\text { to emergency department. }\end{array}$ & $\begin{array}{l}\text { Quality/quantity of care } \\
\text { provided (-) }\end{array}$ \\
\hline & & & & & & $\begin{array}{l}\text { Physicians paid by capitation method } \\
\text { enrolled fewer new patients than those } \\
\text { paid by fee-for-service. }\end{array}$ & Provider attitude (-) \\
\hline & & & & & & $\begin{array}{l}\text { There was no difference in the compre- } \\
\text { hensiveness and continuity of care } \\
\text { between capitated and fee-for-service } \\
\text { patients. }\end{array}$ & Quality of care $(+)$ \\
\hline \multirow[t]{2}{*}{7.} & \multirow[t]{2}{*}{$\begin{array}{l}\text { Cykert et al. } \\
(1997)\end{array}$} & \multirow[t]{2}{*}{ USA } & \multirow{2}{*}{$\begin{array}{l}\text { To assess physicians' } \\
\text { attitude towards HMOs } \\
\text { that utilize capitation pay- } \\
\text { ment for reimbursement of } \\
\text { services. }\end{array}$} & \multirow{2}{*}{$\begin{array}{l}\text { Electronic-based na- } \\
\text { tional survey using self- } \\
\text { administered question- } \\
\text { naires }\end{array}$} & \multirow[t]{2}{*}{$\begin{array}{l}482 \text { out of } 899 \text { eligible } \\
\text { primary care physi- } \\
\text { cians responded. }\end{array}$} & $\begin{array}{l}\text { Primary care physicians had negative } \\
\text { perception about the capitation payment } \\
\text { method. }\end{array}$ & Provider attitude (-) \\
\hline & & & & & & $\begin{array}{l}\text { Primary care physicians worked better } \\
\text { within capitated payment regime. }\end{array}$ & Provider attitude $(+)$ \\
\hline \multirow[t]{2}{*}{8.} & $\begin{array}{l}\text { Hennig- } \\
\text { Schmidt } \\
\text { al, 2011 }\end{array}$ & Germany & $\begin{array}{l}\text { To improve understanding } \\
\text { on how incentives from the } \\
\text { payment systems FFS and } \\
\text { CAP influence Physicians } \\
\text { behaviour }\end{array}$ & $\begin{array}{l}\text { Experimental investiga- } \\
\text { tion (controlled labora- } \\
\text { tory experiment) }\end{array}$ & 42 medical students & $\begin{array}{l}\text { Physicians provide medical services } \\
\text { significantly lower than optimal for } \\
\text { patients in capitation payment regime } \\
\text { but provide services significantly high- } \\
\text { er than optimal for patients in fee-for- } \\
\text { service practice. }\end{array}$ & $\begin{array}{l}\text { Provider atti- } \\
\text { tude/quality/quantity of } \\
\text { care provided (-) }\end{array}$ \\
\hline & & & & & & $\begin{array}{l}\text { Physicians paid by capitation method } \\
\text { underserve patients in bad and interme- } \\
\text { diate state of health while patients in } \\
\text { good and intermediate state of health } \\
\text { are over served by those paid by fee- } \\
\text { for-service method }\end{array}$ & $\begin{array}{l}\text { Provider atti- } \\
\text { tude/quality/quantity of } \\
\text { care provided (-) }\end{array}$ \\
\hline \multirow[t]{2}{*}{9.} & \multirow[t]{2}{*}{$\begin{array}{l}\text { Sorbero E.S } \\
\text { et al, } 2003\end{array}$} & \multirow[t]{2}{*}{ USA } & \multirow{2}{*}{$\begin{array}{l}\text { To examine the relation- } \\
\text { ship between patient case } \\
\text { mix, utilization, primary } \\
\text { care physician (PCP) pay- } \\
\text { ment method and the prob- } \\
\text { ability that patients will } \\
\text { switch their PCP }\end{array}$} & \multirow[t]{2}{*}{$\begin{array}{l}\text { Conceptual model Ret- } \\
\text { rospective administra- } \\
\text { tive data, (multivariate } \\
\text { analysis) }\end{array}$} & \multirow[t]{2}{*}{$\begin{array}{l}67,131 \text { patients and } \\
682 \text { PCPs. }\end{array}$} & $\begin{array}{l}\text { Patients whose primary care providers } \\
\text { were paid by capitation method were } \\
36 \% \text { more likely to switch their provid- } \\
\text { er than those with fee-for-service-paid } \\
\text { provider. }\end{array}$ & $\begin{array}{l}\text { Patient-provider relation- } \\
\text { ship / patients (-) }\end{array}$ \\
\hline & & & & & & $\begin{array}{l}\text { Patients with high utilization behaviour } \\
\text { were significantly more likely to switch } \\
\text { capitated provider than were similar } \\
\text { patients of FFS-paid provider. }\end{array}$ & $\begin{array}{l}\text { Patient-provider relation- } \\
\text { ship / patients (-) }\end{array}$ \\
\hline 10. & $\begin{array}{l}\text { Pereira } \text { G. } \\
\text { Ann et al, } \\
2001\end{array}$ & USA & $\begin{array}{l}\text { To assess patient attitude } \\
\text { towards physician com- } \\
\text { pensation model and to } \\
\text { explore patients' character- }\end{array}$ & $\begin{array}{l}\text { Cross-sectional (elec- } \\
\text { tronic) survey }\end{array}$ & $\begin{array}{l}2,000 \text { adult patients in } \\
\text { New England HMO }\end{array}$ & $\begin{array}{l}\text { Patients who knew their primary care } \\
\text { physician was paid through capitation } \\
\text { frequently expressed discomfort with } \\
\text { capitation payment. }\end{array}$ & $\begin{array}{l}\text { Patient-provider relation- } \\
\text { ship / patients (-) }\end{array}$ \\
\hline
\end{tabular}




\section{Original Article}

\begin{tabular}{|l|l|l|l|l|l|l|}
\hline & & & $\begin{array}{l}\text { istics associated with these } \\
\text { attitudes. }\end{array}$ & $\begin{array}{l}\text { Wealthier and more educated patients } \\
\text { were more likely to express their dis- } \\
\text { comfort with capitation payment. }\end{array}$ & $\begin{array}{l}\text { Patient-provider relation- } \\
\text { ship / patients (-) }\end{array}$ \\
\hline 11. & $\begin{array}{l}\text { Hall et al. } \\
(2002)\end{array}$ & USA & $\begin{array}{l}\text { To assess the impact on } \\
\text { trust of disclosing HMOs' } \\
\text { primary care physicians' } \\
\text { payment methods to their } \\
\text { enroles. }\end{array}$ & $\begin{array}{l}\text { Hisclosing the positive and negative } \\
\text { features of incentives and increasing } \\
\text { knowledge of them does not reduce } \\
\text { trust in physicians or insurers and may } \\
\text { have mild positive impact on physician } \\
\text { trust. }\end{array}$ & $\begin{array}{l}\text { Patient-provider relation- } \\
\text { ship / patients }(+)\end{array}$ \\
\hline
\end{tabular}

